\title{
Engendering Economic Recovery: Modelling Alternatives to Austerity in Europe
}

\author{
By \\ Hannah Bargawi, SOAS, University of London, UK \\ and \\ Giovanni Cozzi, FEPS, Brussels, Belgium
}

\begin{abstract}
$^{1}$
This article explores a gendered expansionary macroeconomic scenario for Europe as an alternative to the current direction of austerity policies over the medium to long-term. Using a macroeconomic forecasting model we demonstrate that the dual aim of economic growth and increases in both male and female employment can be achieved via the adoption of gendersensitive expansionary macroeconomic policies and by overturning austerity policies. Projections for our gendered expansionary macroeconomic scenario suggest that an additional 14 million jobs, of which 9 million are for women, could be created by 2030 in the Eurozone and the United Kingdom by reversing austerity policies and marshalling government expenditure and investment towards female and male employment. We also show that these positive results are not achieved at the expense of high levels of debts and fiscal deficits. The main recommendation is for Europe to roll back austerity policies and to embark on a new gender-focused economic trajectory.
\end{abstract}

\section{KEYWORDS}

Europe, austerity measures, recovery, gendered macroeconomic policies.

\footnotetext{
${ }^{1}$ This work has been made possible by generous financial support from FEPS, Brussels and SOAS, University of London. The authors received helpful comments from participants of the 'Beyond Austerity, Towards Employment: A Gender Aware Framework' seminar, held in Brussels in February 2014. Thanks also to Lorena Lombardozzi for excellent research assistance and to Terry McKinley to comments on an earlier draft.
} 


\section{Introduction}

Job creation for both men and women should be a high priority for European policy makers given the unsustainable high levels of unemployment rate in the aftermath of the financial crisis and the persistent employment gap between men and women across Europe. Instead, economic policies to date have overwhelmingly focused on attempts to cut both government debt and deficit by adopting a series of austerity measure with negative consequences for job creation and growth.

This paper explores a gendered expansionary macroeconomic scenario for Europe as an alternative to the current direction of austerity policies. This alternative scenario focuses on the need to generate higher growth, to create jobs across Europe, and to narrow the gap between female and male employment rates in Europe. We base our assumption on existing empirical evidence which shows that policies focusing on employment generation and investment are one of the best strategies for stimulating future growth and, crucially, for reducing government debt in the medium to long term (see e.g. Terry McKinley and Giovanni Cozzi, 2011, Stephanie Griffith-Jones, Matthias Kollatz-Ahnen, Lars Andersen and Signe Hansen 2012 and Terry McKinley, Giovanni Cozzi, Jo Michell, and Hannah Bargawi 2013a, among others).

Using a detailed macroeconomic model in this paper we complement the existing empirical evidence by developing a gendered perspective on employment-based economic recovery. This is of particular importance in light of increased evidence that current austerity policies in Europe are likely to disproportionately disadvantage women via their roles in the labor market (see e.g. Maria Karamessini and Jill Rubery 2013 and Francesca Bettio et al. 2013).

In order to achieve this objective, our paper compares and contrasts two alternative scenarios for Europe: an austerity scenario and a gendered expansionary macroeconomic scenario. In the austerity scenario we assume that the current fundamental direction of austerity policies is maintained to 2030 while in our gendered expansionary macroeconomic scenario we use government spending and investment, and private investment to reach specific targets for female and male employment. In other words, we assume that governments do not drastically cut public investment and expenditure and that private investment significantly increases in an effort to generate the economic momentum required to substantially raise employment levels for both men and women.

The focus of this paper is on the Eurozone and the United Kingdom. We divide the Eurozone into two blocs: Core Eurozone (Austria, Germany, Belgium, France, Luxemburg and The Netherlands) and Eurozone Periphery (Italy, Ireland, Spain, Portugal and Greece). Eurozone countries have been aggregated on the basis of similar macroeconomic conditions. Further, we keep the Eurozone Periphery as an individual bloc as it exhibits much lower rates of female employment compared to the Core Eurozone.

Results generated by the CAM model for the gendered expansionary macroeconomic scenario project significantly higher levels of both male and female employment than the austerity scenario and thus lead to a significant reduction in the employment gap between men and women. The reduction in the employment gap between men and women in our alternative scenario also has positive effects on both labor productivity and on the available amount of government spending per dependent. In addition, the combination of higher levels of growth and increased government revenue lead to a significant reduction in both government debt and fiscal deficits in our scenario. As such the gendered expansionary macroeconomic scenario cannot be dismissed on the basis of fiscal profligacy or for generating excessive government debt.

Thus, we conclude by arguing that a gender-aware expansionary macroeconomic framework for Europe is indeed economically viable and it provides significantly better 
perspectives not only in terms of job creation for women and men but also in terms of debt reduction and fiscal balances.

While there is a growing literature on the impact of austerity on men and women, and alternative proposals to narrow the employment gap between men and women this paper makes an original contribution in that it is, to our knowledge, the first attempt to quantify and assess the overall economic feasibility of a gender-sensitive expansionary macroeconomic strategy for Europe.

\section{What do we know about the impact of the crisis and austerity policies on men and women in Europe's labor market?}

Initially, the global financial crisis led to a decline in domestic and global demand in maledominated manufacturing, construction, and financial sectors. However, as crisis turned to recession across Europe, secondary impacts via private sector demand have been less genderspecific, affecting a range of industries and leading to job cuts, wage freezes and increased job insecurity for both men and women (Stephanie Seguino 2010; Karamessini and Rubery 2013). A further dimension to these first and second-round job cuts is pointed out by Seguino (2010), making use of results from latest round of the World Values Survey. In developed as well as developing countries gender norms around who has a greater right to a job often persist, so that 'women are frequently fired first, because men are perceived to be the legitimate jobholders when jobs are scarce.' (Seguino 2010: 181)

Examples from Italy (Alina Verashchagina and Marina Capparucci 2013), Spain (Elvira Gago and Marcelo Kirzner 2013), and Greece (Maria Karamessini 2013), while demonstrating the variety in the channels and intensity of impacts of the crisis, also highlight a number of trends and commonalities regarding gender aspects. In general, the crisis has stalled progress towards gender equality, both in terms of pay and conditions as well as reducing the absolute number of women in formal employment. Where a narrowing of gender equality has taken place this has, unfortunately, been achieved 'through the deterioration of employment and social conditions for both men and women.' (Karamessini 2013: 183)

Despite the significant deterioration in employment opportunities for both men and women as a result of the global crisis and recession, policy responses across Europe, following temporary, piece-meal and early attempts at fiscal stimulus, have focused on fiscal containment and debt reduction rather than promoting growth and job creation (Bettio et al 2013: 120). The preoccupation with fiscal deficits and government debts has led governments to implement harsh austerity policies in order to significantly reduce government expenditures, with negative repercussions on public sector employment, welfare and public investment. Isabel Ortiz and Matthew Cummins (2013) conduct a review of austerity measures across 181 countries, relying on IMF country reports published since 2010 to document policies across the following seven categories: i) eliminating or reducing subsidies; ii) cutting or capping the wage bill; iii) increasing consumption and sales taxes; iv) reforming old age pension, usually to increase the age of eligibility for men and women; v) rationalising safety nets; vi) healthcare systems reform; vii) labor flexibilization reform (e.g. removal or minimum wages). Table 1 summarizes their results.

\section{INSERT Table 1: Review of austerity measures across Europe}

Missing from Ortiz and Cummins (2013a) original analysis is an assessment of how policies under the above categories affect different groups of people within each country, including women as opposed to men. However, an updated study by the authors (2013b), does highlight the ways in which vulnerable groups are impacted by each of the above categories within developing countries. They conclude as follows. 
"The adverse effects of the main austerity measures being adopted were also likely to be disproportionately felt by children and women: wage bill reductions can hamper the delivery and quality of essential health, nutrition, and education goods and services, especially in rural areas; subsidy reversals can make food, transport, and other basic goods unaffordable; and rationalizing social protection schemes, including pension benefits, runs a high risk of exclusion at a time when children and women are most in need." (Isabel Ortiz and Matthew Cummins 2013b: 73)

There has been a gradual recognition among gender experts that such policies are significantly shifting the burden of debt and budget deficit adjustment on to women in both developed and developing countries (Seguino 2010; Zita Gurmai 2013; Karamessini and Rubery 2013; UNISON 2014). The European Women's Lobby (EWL) (2012) has detailed the ways in which women across Europe have been acutely affected by such austerity policies both inside and outside the labor market. In many instances cut-backs to state-provided care services are seeing women return to their traditional gender roles, stepping out of formal employment to take over caring responsibilities no longer funded by the state. The EWL (2012) report also highlights the increasing precariousness of lone mothers and female pensioners, due to their heightened reliance on state-funded services, currently under threat from cut-backs.

Beyond the direct impacts via the labor market, there are a number of ways in which women are impacted by austerity policies indirectly as well. Increases in the retirement age, the removal of or tightening of criteria relating to certain benefits (e.g. housing benefit), and the rise in out-of-pocket health spending are all additional examples of ways in which expenditure cuts are hitting households, and women in particular, outside of the labor market. For example, current pension reforms in the case of Greece (Karamessini 2013) demonstrate the way in which women are penalised as a result of having shorter and irregular work histories.

The focus on this paper in on assessing the impact of austerity policies on men and women via the labor market, in particular, and on demonstrating what an alternative framework for Europe might look like. We therefore focus the following discussion of gendered labor market impacts under two main headings (i) direct public sector employment impacts, and ii) indirect public spending effects, before identifying the roots of an alternative framework that moves away from austerity economics.

\section{Public sector employment impacts}

Cuts in government expenditure have led to a further reduction in female-dominated public sector jobs and pay. Even early indications from a study conducted in 2010-11 in four countries in Europe, indicated that public sector job cuts have been a widespread feature of austerity policies, with women disproportionately affected (European Federation of Public Service Unions 2011). Recruitment freezes or job cuts have also resulted in increased working intensity (longer hours, fewer holidays, and less family-friendly shift patterns) for those remaining in employment. Women have been disproportionately affected by such changes. (see Gago and Kirzner 2013 for examples of this in the Spanish context).

A brief glance at more recent EUROSTAT data reveals the opposing trends regarding male and female public sector employment across the Eurozone. In the Core Eurozone male full-time public sector employment (MFTPSE) has declined moderately since 2010. In 2013 levels were $97 \%$ of the pre-austerity levels of 2010. In the Eurozone Periphery the falls in MFTPSE have been more dramatic, reaching just 92\% of 2010 levels in 2013. However, across both regions part-time public sector employment has increased for males. In the Core 
Eurozone the increase in male part-time public sector employment (MPTPSE) has been moderate but in the South Eurozone such as increase has been particularly relevant, rising to above $120 \%$ of 2010 levels in 2013.

Of interest to us, are the different trajectories followed by female counterparts in the Core and Periphery Eurozone. While female full-time public sector employment (FFTPSE) has remained stable in the Core Eurozone, FFTPSE in the Eurozone Periphery has declined almost as sharply as for men. However, in contrast to the situation for men, female part-time public sector employment (FPTPSE) has not risen in the same way as for men in this region. Instead levels of FPTPSE have only witnessed a marginal increase.

\section{INSERT Figure 1: Public sector employment in the Eurozone (2010-2013)}

The above data suggests a sharp gender contrast in public sector employment in the Eurozone Periphery. While male full-time employment in the public sector has declined, parttime employment has made up for some of these falls. It would appear that, however, such part-time employment in the public sector has not played the same role for women laid off from full-time employment in the public sector in the Eurozone Periphery.

Considering trends in the public sector gender pay gap can help us further understand the gender dimension to public sector cuts. The unadjusted Gender Pay Gap (GPG) represents the difference between average gross hourly earnings of male paid employees and of female paid employees as a percentage of average gross hourly earnings of male paid employees. As such a reduction in the GPG represents progress towards equal pay between men and women. Table 2 below highlights the progress achieved regarding the GPG in the public sector since 2008 (in this instance the health and education sectors in countries for which such data is available). Across all countries (with the exception of Spain), the GPG in the public sector has been on the decline. A closer look, however, reveals that such progress has stalled since austerity measures were adopted in 2010. A simple average reveals that progress towards equal pay is in jeopardy in both the Eurozone Periphery and Core, with countries such as Ireland, Spain and France showing particularly worrying trends.

\section{INSERT Table 2: The gender pay gap in the public sector in Europe (2008-2012)}

\section{Public spending effects}

Cuts in care-related spending or increased eligibility criteria for receiving support towards (child and/or elderly) care costs and family benefits have hit women in the labor market in particular. Many have reduced their work commitments or have left the labor market entirely as a result of such an increase in costs (Karamessini and Rubery 2013). Eurostat data indicates a general reduction in public spending across the Eurozone countries and the UK, with Eurozone Periphery countries witnessing stronger reductions in public expenditure since 2010. This picture can be broken down further.

Spending on old-age services has remained relatively stable across all countries. Similarly spending on health services, in general has remained around 14\%-16\% of GDP across Eurozone countries (Eurostat 2014). However, once data on spending per person are considered different trajectories emerge in the Periphery and Core Eurozone. While in the Core Eurozone health spending per person per annum has increased from an average of $€ 2730$ in 2010 to $€ 2900$ in 2012, in the Eurozone Periphery there has been an average reduction of health spending per person from $€ 1730$ in 2010 to $€ 1560$ in 2012.

Spending on children's services and education has followed a similar trajectory. While spending on family and child services has remained relatively stable over the last few years, 
education spending per child has been reduced by a significant margin in Eurozone Periphery countries. While in the Eurozone Core average public education spending per child (under $15)$ per annum has increased marginally year on year since 2008, in the Eurozone Periphery countries such spending has, on average, been reduced from $€ 7540$ in 2010 to $€ 6760$ in 2012 per child per annum.

The impacts of such a reduction in spending on essential public services on female employment can be seen in the data on discouraged workers. In the Eurozone periphery female workers have been particularly discouraged from (re)entering the jobs market since 2010. While in 2010 the percentage of discouraged workers in the Eurozone Periphery represented around 5.6\% of the total active population, by 2013 that figure had reached $7.2 \%$.

\section{INSERT Table 3: Female discouraged workers ${ }^{2}$ as a \% of total active population} (2008-2012)

The overall picture that emerges from the above consultation of recent literature and data is an unambiguous one. Austerity policies are beginning to expose clear gender divisions, especially in the Eurozone Periphery. Women are feeling the impact of such policies both directly, via their reduced employment in the public sector but also indirectly via the reduction of public sector spending on crucial care, health and education services that have, in the past, supported working women. Given this status-quo it is crucial that we highlight the nature and content of a gendered alternative to austerity economics.

\section{Developing alternative policies further from a gender-perspective}

A significant discussion on alternative policy proposals for economic recovery has recently emerged from a number of different arenas. These proposals are based on the recognition that austerity policies are detrimental for Europe and that jobs and growth are created only with the adoption of an expansionary macroeconomic framework (see Nitika Bagaria, Dawn Holland and John Van Reenen 2012; Michael Dauderstaedt and Ernst Hillebrandt 2013; McKinley et al. 2013a; Griffith-Jones et al. 2012; and McKinley and Cozzi 2011). A particularly illuminating aspect of this research have been attempts, using the CAM as well as other macroeconomic models, to demonstrate the medium to long-term desirability of adopting alternative macroeconomic policies in Europe, for growth and job creation in general. However, currently missing from the above studies, have been attempts to estimate the potential gender impacts of different policy scenarios.

Concurrently to the above research agenda, a number of feminist scholars have begun to demonstrate what a progressive, feminist alternative to continued austerity might constitute in concrete policy terms (Claire Annesley 2014; Diane Perrons and Ania Plomien 2013; Women's Budget Group 2012). In the UK, the Women's Budget Group (2012) has devised a so-called F-Plan. This alternative, feminist plan for recovery outlines policies that stimulates job creation by putting money in the hands of poorer and middle-income people and invests in social as well as physical infrastructure. The F-plan covers tangible measures to reverse current and planned expenditure cuts of the UK government by reintroducing important benefits, such as child care allowances and pensioner benefits. The F-plan also outlines important progressive revenue-raising policies, supporting an international financial transaction tax and raising taxes from higher income earners. Finally, the F-plan details how financial and investment policies can be made more gender-equitable, for example via the rebalancing of investments towards social and human infrastructure as well as physical infrastructure. These concrete proposals are an important addition to current debates around

${ }^{2}$ Discouraged workers are identified as persons available to work but not seeking work. 
the impact of the financial crisis and austerity policies on men and women in Europe. Such policy proposals also fill the gender-gap identified among those working on macroeconomic policies for broad-based recovery in Europe.

Finally, it is important to note the progress made regarding the engendering of macroeconomic models among feminist scholars. Recent works by Elissa Braunstein, Irene Van Staveren and Daniela Tavani (2011) and Marzia Fontana (2014) demonstrate the limits of traditional macroeconomic models of the economy and the limits to investigating gender as merely an add-on to traditional categories of analysis. Braunstein, Van Staveren and Tavani (2011) offer an important addition to the literature in this field by formally modelling the unpaid care sector as part of the economic system. In general, attempts to engender macroeconomic models have remained within the realm of the short to medium term. Therefore very little can be said on the basis of this (mostly theoretical) work about concrete changes in policies and gendered outcomes in the longer-term. This article, by making use of a non-conventional macroeconomic model, hopes to add to this research by providing a longer-term perspective.

This article intends to borrow from the different strands of research discussed above, and build on the research and policy status quo. The intention is to investigate the engendering of the general macroeconomic alternatives to continued austerity, by implementing the measures and policies emerging from feminist scholarship. As such, the article is able to demonstrate the economic feasibility of a gender-equitable macroeconomic scenario that puts long-term growth and job creation at its heart.

\section{The Cambridge-Alphametrics model (CAM)}

In section 2 we presented some of the gendered impacts of current austerity policies via labor market outcomes in the short to medium-term, relying on currently available Eurostat data and evidence from secondary literature. But what are the broader, long-term consequences of continued austerity versus alternative policy measures? We hope to answer this question by making use of a global macroeconomic model that allows us to compare and contrast opposing policy scenarios. While this model does not allow us to consider the long-term gender outcomes in specific sectors, it does allow us to investigate the impacts of different policies on men and women in the labor market and on broader economic variables in each of our countries of interest.

The Cambridge-Alphametrics Model (CAM) of the world economy is a non-conventional global macroeconomic model that is primarily used to make medium- to long-term projections of historical trends of the global economy, blocs of countries, and major individual countries. This macro-model does not have any single, well-defined equilibrium path to which the world economy tends to return in the medium or long-term. Being an open disequilibrium system, a wide variety of outcomes may be simulated with different growth rates and end points (Francis Cripps 2014). ${ }^{3}$

CAM projections draw on continuous historical data from 1970 to the most current year available for model variables (2012 for this exercise). The databank holds series in US dollar values and other units disseminated by UN organizations.

In CAM the world economy is regarded as an integrated system in which the behaviour of different countries and blocs differs and changes progressively through time because of their specific situation in terms of geography, level of development, financial position, and so forth. The macro-model has a common set of identities and behavioural equations for all blocs to reflect the notion that they are part of the same world economy. This common

\footnotetext{
${ }^{3}$ This section draws expensively from Cripps (2014).
} 
schema allows for panel estimation methods, which are advantageous when there is considerable variation in the accuracy of series from different groups of countries and time periods (Cripps 2014).

Behavioural equations are specified with functional forms that make it possible for responses in different parts of the world and at different levels of development to be modelled with common structural parameters with explicit identifications of the main reasons for differences between blocs. Techniques that facilitate use of the common schema include bloc specific intercepts and error variances, error-correction dynamics, and transformation and scaling of variables (Cripps 2014).

Unless behavioural constraints are introduced into the model, aggregate demand and technical progress are the principal drivers of economic growth. Thus, growth rate is best understood as reflecting growth of aggregate investment and government spending in the world as a whole. These variables in turn reflect confidence and expectations on the one hand (private investment) and policy on the other (government spending) (Cripps 2014).

The model structure is implemented by equations fixing the value of a large number of macro-economic variables for each bloc and year, some of which are identities (i.e. the equation must always hold exactly) and other behavioural in nature with residual terms that represent departures from normal regular behaviours specified by constants and explanatory variables with structural coefficients determined by panel estimation (Cripps 2014).

Below we report some of the core variables and equations of the CAM model which form the basis of the scenarios built in this paper.

\section{Income and expenditure}

Gross national income $Y$ is distributed and spent by government and the private sector. The source of gross national income are output (GDP), net receipts of income and transfers from other countries and additions to or subtractions from domestic purchasing power arising from changes in the external terms of trade.

Private disposable income is defined as national income not absorbed by the government:

(1) $Y p=Y-Y g$

Private consumption expenditure is determined by income and savings behaviour:

(2) $C=Y p-S p$

The saving rate responds to changes in income $Y p$ and wealth $W p$ and is influenced by inflation and short-term interest rate.

Private fixed investment shows a standard accelerator pattern responding to the rate of growth of GDP $d \log (V)$ and financial conditions such as the rate of bank lending, $I L N$, and the real bond rate, irm:

$$
\begin{aligned}
& d \log \left(I p / V_{-1}-0.05\right)=f\left(-\log \left(I P_{-1} / V_{-2}-\right.\right. \\
& \left.0.5),+\operatorname{dlog}(V),+I L N_{-1} / V_{-1},-i r m, a_{b}, e_{b}\right)
\end{aligned}
$$

The symbols $a_{b}$ and $e_{b}$ denote the bloc-specific intercepts (long-run values) and disturbances.

\section{Government accounts}


Changes in government debt $L_{g}$ depend on the balance between government spending and revenue and on asset transactions and write-offs and holding gains and losses. Government income $Y_{g}$ (revenue less subsidies, transfers and interest payments), is limited to $40 \%$ or less of prior year national income $Y_{-1}$ and responds positively to increases in national income $Y$, especially in the first year. Other factors influencing government income in the long run are the inherited stock of debt $L G / Y$ and cost of financing the debt including the impact of real bond rates irm:

$$
\text { (4) } \begin{gathered}
-\operatorname{dlog}\left(\begin{array}{l}
0.4 Y_{-1} / Y g-1 \\
)
\end{array}\right) f\left(+\log \left(0.4 Y_{-2} / g_{-1}-1\right),+\operatorname{dlog}(Y),-\operatorname{dlog}\left(Y_{-1}\right)\right. \text {, } \\
\left.+\log \left(L G_{-1} /_{Y_{-1}}\right),-i r m_{-1} L g_{-1} /_{Y_{-1}}, a_{b} e_{b}\right)
\end{gathered}
$$

Government spending on goods and services $G$ responds to the level and rate of change of government income $Y g$ and tends to rise with population $N$. Government spending is also adjusted in response to the inherited debt burden $\mathrm{LG}_{-1} / \mathrm{Y}_{-1}$, and the external current account $C A \$_{-1} / Y \$_{-1}$ :

(5)

$$
\begin{aligned}
& d \log (G)= \\
& f\left(-\log G_{-1}\right),+d \log (Y g),+Y g_{-1} /_{Y_{-1}},+\log \left(N_{-1}\right),-\log \left(L G_{-1} /_{Y_{-1}}\right),+C A \$_{-1} / Y \$_{-1}, a_{b} e_{b}
\end{aligned}
$$

The financial balance or 'net lending' of government $N L g=Y g-G$ represents the difference between income and spending on goods and services.

\section{Population and employment}

Employment of women NEF and men NEM is a function of potential labor supply represented by population aged 15-64 (NWP) and fluctuations in GDP growth $d \log (V)$ with an elasticity that increases with relative per capita income $Y R$. Other factors are the size of the child population $N C P$ and the degree of urbanization $N U R$ affecting female and male employment, respectively ${ }^{4}$. A transformation is applied to ensure that the proportion of employed lies within a range of $15-70 \%$ for women and $49-95 \%$ for men:

(6) $d(N E A f)=$

$$
f\left(-N E A f_{-1},-\log \left(N C P_{-1} /_{N_{-1}}\right),+Y R_{-1} d \log V,+Y R_{-1} d \log \left(V_{-1}\right), a_{b} e_{b}\right.
$$

(7) $d(N E A m)=$

$$
f\left(-N E A m_{-1},-\log \left(N U R_{-1} /_{N_{-1}}\right),+Y R_{-1} d \log V,+Y R_{-1} d \log \left(V_{-1}\right), a_{b} e_{b}\right.
$$

Where $N E A x=\log N E x /(N W P x-\min ) /(\max -\min )-1)$

Natural increases in population up to 2030 are treated as predetermined (using UN Population Division median estimates). Population projections are however affected by net migration $N I M$ which responds to relative per capita income $Y R$ and employment growth $\operatorname{dlog}(N E)$ with considerable momentum implied by the lagged dlog term:

\footnotetext{
${ }^{4}$ For a full explanation of the determinants of male and female employment, see Cripps 2014.
} 
(8) $\begin{gathered}d \log \left(1+N I M / N E_{-1}\right)=f\left(-\log 1+N I M_{-1} / N E_{-2}\right),+d \log \left(1+N I M_{-1} / N E_{-2}\right),+Y R_{-1} \text {, } \\ +d \log (N E), a_{b} e_{b}\end{gathered}$

Migration projections, like other international exchanges, are adjusted to make sure that net migration is zero for the world as a whole (Cripps 2014).

\section{Scenario assumptions and specifications}

This paper compares and contrasts two alternatives for Europe for the period to 2030. The first scenario assumes the continuation of past trends and current austerity policies without any significant innovation in European politics (Austerity scenario). This scenario is then contrasted with a Gendered Expansionary Macroeconomic scenario which assumes a rollback of current austerity policies and that gendered reflationary fiscal policies together with private investment are the key drivers for stimulating future growth and creating jobs for men and women in Europe. We now review the core assumptions underpinning the two scenarios under investigation.

\section{Austerity scenario}

In the austerity scenario we assume that governments in the Eurozone and in the United Kingdom will continue to cut expenditures in an attempt to reduce budget deficits and bring their debt-to-GDP ratio down to 60\%, in line with the Growth and Stability Pact. In order to achieve this, we impose targets for the ratio of government expenditure to GDP (GV) for the Core Eurozone, Eurozone Periphery, and for the United Kingdom (Table 4).

\section{INSERT Table 4: Target government expenditure 5 as percentage of GDP under austerity and historical values}

The 2030 targets for government expenditure to GDP are $21 \%$ for the Core Eurozone, $20 \%$ for the United Kingdom, and 19\% for the Eurozone Periphery. This represents a reduction in government expenditure from the period 2012 to 2030 of $13 \%$ for the Core Eurozone, $20 \%$ for the United Kingdom and of 24\% for the Eurozone Periphery.

In addition to cuts in government expenditure, and in order to further decrease fiscal deficits, we also assume modest increases in government revenue in the Eurozone Periphery and in the United Kingdom.

\section{INSERT Table 5: Target government income as percentage of GDP under austerity and historical values}

The 2030 targets for the ratio of government net income to GDP (YgV) are $20 \%$ for the Eurozone Periphery and 19\% for the United Kingdom, up from 18\% in 2014 in both blocs..

\footnotetext{
${ }^{5}$ Government expenditure excludes transfer payments such as social security and pensions. Thus the ratios shown are considerably smaller than the gross figure usually quoted.
} 
The 2030 target of government net income to GDP for the Core Eurozone is $20 \%$ and the starting level in 2012 is also $20 \%{ }^{6}$.

In the austerity scenario we also assume that private investment will continue its historical trend into the future and thus remains subdued in the face of sluggish GDP growth and depressed expectations of profitability. As such, we do not programme for any specific target (boost) for private investment as percentage of GPD (IpV) by 2030 and instead we project the historical trends into the future for all the blocs under investigation.

\section{Gendered expansionary macroeconomic scenario}

In our gendered expansionary macroeconomic scenario we assume that government investment and expenditure together with private investment are the key drivers for stimulating future growth and for generating jobs for both men and women. Thus, in this scenario we roll back austerity policies, maintain or even increase government investment, as government expenditure is not drastically cut as in the austerity scenario, and we also assume increased private investment. Government expenditure and investment, together with private investment, are then marshalled towards employment generation for both women and men.

The key target variable in this scenario is the ratio of the employed to working-age population (NERW). We calibrate the size of investment and fiscal stimulus in order to achieve a desirable, but also feasible, level of this ratio for the three blocs. Table 6 shows the 2030 target, the intermediate 2020 target (to allow comparison with the EU 2020 strategy targets) and the historical values, for employed to working-age population for the Core Eurozone, the Eurozone Periphery, and the United Kingdom.

\footnotetext{
${ }^{6}$ The slight increases in government new income in the Eurozone Periphery and the United Kingdom are assumed to originate from clamping down on tax evasion and tax fraud, and from the introduction or increases in indirect taxation, such as VAT. See Ortiz and Cummins 2013a for the full range of policies across these countries. However, we do not assume any increase in government net income to GDP for the Core Eurozone as its fiscal position is viable at the beginning of the period under investigation. .
} 


\section{INSERT Table 6: Employment as percentage of working-age-population: targets and historical levels}

In case of the Core Eurozone and the United Kingdom the employment targets for 2030 are $79 \%$ and $77 \%$ respectively. The intermediate 2020 target is $73 \%$ for both the Core Eurozone and the United Kingdom. This intermediate target for the Core Eurozone is in in line with the European Commission Europe 2020 estimated EU target of 73-74\% (European Commission 2013). The United Kingdom has not set up any employment target for 2020. However, we use the 2020 target for the Core Eurozone as a proxy for establishing the intermediate target for this country.

The 2030 employment target for the Eurozone Periphery is $71 \%$ and the intermediate target in 2020 is 64\%. The intermediate target for this bloc is lower than the Europe 2020 employment target. The European Commission estimates an average employment target for this bloc of $71 \%$ in 2020 (European Commission 2013). However, given the persistent recessionary conditions in the Eurozone Periphery, the low expectations of profitability under continued austerity policies, and the historical trend of the past decade, we believe that the target set up by the European Commission for this bloc in 2020 is far too optimistic.

In addition, in our gendered expansionary macroeconomic scenario, we programme for a disproportionate increase in female employment vis-à-vis male employment. In other words, we assume that government spending and investment is directed more towards the creation of jobs for women than men. Thus, the assumed growth rate of the ratio of female employment to female working-age population (NERFW) is higher than the growth rate of male employment to male working-age population (NERMW). Table 7 shows the targets for female employment as a percentage of female working-age population and for male employment as a percentage of male working-age population. 


\section{INSERT Table 7: female and male employment targets}

These employment targets are achieved through a combination of reflationary fiscal policies (maintaining or even increasing government spending and investment levels) and a significant rise in private investment. On the one hand, with regards to government spending, we let the model determine the required level to meet the employment targets. In other words, rather than setting specific targets for government expenditure as percentage of GDP (GV) we let the model identify the required level of government expenditure needed to reach the assumed employment targets ${ }^{7}$.

For private investment, on the other hand, we assume exogenous increases to counter the declining historical trends.

We believe that private investment will have to significantly increase from the woefully low levels to which it is has fallen following the financial crisis in order spearhead economic recovery and create jobs. Thus, we programme increases in private investments as a ratio to GDP (IpV) in the three blocs in order to bring them back to early 2000s levels. Table 8 shows the private investment targets and the historical values for the Core Eurozone, the Eurozone Periphery and the United Kingdom.

\section{INSERT Table 8: private investment targets and historical values}

With regards to the financing of private investment we assume that increases in private investment could be financed through enhanced lending from the European Investment Bank (EIB) and by a better allocation of EU structural funds and the European Social Fund. These funds could be used for financing economically sustainable projects and activities, support the growth of both existing and new competitive enterprises, and especially those that provide skills upgrading and training for both women and men and provide family friendly working patters and child care.

We believe that such a combination of reflationary fiscal policies together with increases in private investment should help expand the productive capacity of an economy in addition to stimulating aggregate demand. Further, by disproportionately redirecting government investment and expenditure towards supporting female employment we assume that women will benefit the most from the expansion of productive capacity. That is, we assume that part of this government expenditure and investment will be redirected towards enhancing physical and human capital for women, enabling them to (re)enter the labor market.

Finally, in order to contain possible fiscal deficits that might result from the implementation of reflationary policies we also assume a boost in government revenue as percentage of GDP $(\mathrm{YgV})$. For all the blocs government revenue is assumed to increase to $22 \%$ of GDP. Increases for the Eurozone Periphery and the United Kingdom are more significant compared to the Core Eurozone. This is because the level of fiscal deficit for the Eurozone Periphery and the United Kingdom is higher than in the Core Eurozone. However,

\footnotetext{
${ }^{7}$ Given that the targets for female employment are substantially higher than their initial level, compared to the male employment targets for all blocs, we assume that government spending will be channelled towards the creation of jobs for women to a greater degree than towards the creation of jobs for men. We rest this assumption on the existing empirical literature which makes the case for significant increases in both human and capital investment towards generating new and better employment opportunities for women across all economic sectors. Governments may do this by providing appropriate training and skills upgrading for women, and supporting industries that offer family friendly working patters and child care (see Karamessini and Rubery 2013; Women's Budget Group 2012; Perrons and Plomien 2013; and Ozlem Onaran 2013 among others).
} 
we believe that these are feasible targets as they are not above historical peaks (22\% for the Eurozone Periphery in 2007 and $23 \%$ for the United Kingdom in 2000). ${ }^{8}$

\section{Results and Analysis}

In this section we present the projections produced by the CAM under the assumptions described for each of the two scenarios.

\section{Employment, welfare and economic growth}

The targets on employment to working age population (including our specific target on female employment to female working age population) are met in our gendered expansionary macroeconomic scenario. We are now interested in assessing how these targets translate into job creation for men and women in the Eurozone.

The gendered employment-led economic recovery scenario achieves important gains both in terms of increases in total female and male compared to the austerity scenario. Table 9 shows the total number of jobs created under the gendered expansionary macroeconomic scenario (alternative) and under the austerity scenario for the three blocs and the historical values.

\section{INSERT Table 9: Total employment (millions of persons)}

Under the austerity scenario total employment is projected to stagnate in both the Eurozone Periphery and in the United Kingdom and to decline by 1.5 million units from 2012 to 2030 in the Core Eurozone. On the other hand, significant employment gains are achieved under the gendered expansionary macroeconomic scenario. By 2030, an additional 4.5 million jobs could be created in the Core Eurozone, whereas in the Eurozone Periphery additional jobs could amount to 8.4 million by 2030. Finally, in the United Kingdom a gendered expansionary macroeconomic framework could lead to the creation of an additional 1.3 million jobs for women and men. Thus, we argue that the combination of private investment boost and reflationary fiscal policies in Eurozone could lead to significant job creation for women and men.

We are now interested in assessing the effects of marshalling government expenditure and investment disproportionately towards supporting female employment. In other words, we identify how many jobs for women are created out of the increases in total employment. Table 10 shows total female employment under the two scenarios for the Eurozone (Core and Periphery) and the United Kingdom.

\footnotetext{
${ }^{8}$ Compared with the austerity scenario, the implicit assumption behind raising government net income in this scenario, is the introduction of progressive tax measures (see Women's Budget Group 2012) as compared to the regressive measures currently proposed or already introduced across Europe (see Ortiz and Cummins 2013a).
} 


\section{INSERT Table 10: Total female employment (in millions)}

In the Eurozone Periphery, where the female employment rate is initially much lower, compared to the North Eurozone, an additional 3.2 million jobs are created for women by 2020 , and this addition could reach 5.8 million jobs by $2030^{9}$. In the Core Eurozone a total of 0.9 million jobs for women could be created by 2020 and this could reach 2.7 million in 2030. Finally, in the United Kingdom the gendered expansionary macroeconomic scenario could generate an additional 0.8 million jobs for women by 2030 . These results are in stark contrast with the austerity scenario where female employment is projected to remain stable in the Eurozone Periphery and in the United Kingdom and even decline in the Core Eurozone. Overall, by redirecting government expenditure towards female employment, in the Eurozone Periphery $70 \%$ of new jobs created are for women and in the United Kingdom and in the Core Eurozone $60 \%$ of new jobs will be for women.

Increases in female employment under the gendered expansionary macroeconomic scenario also lead to a significant increase in the ratio of female employment to male employment, in particular in the Eurozone Periphery. In this bloc, female employment as percentage of male employment increases from $73.8 \%$ in 2012 to $83.7 \%$ in 2030 (Table 11). On the other hand, female employment as percentage of male employment under the austerity scenario declines to $71.6 \%$ thus widening further the employment gap between men and women. In the United Kingdom the ratio of female employment to male employment declined to $85 \%$ by 2030 under the austerity scenario whereas it remains above $86 \%$ under the gendered expansionary macroeconomic scenario. Finally, in the Core Eurozone, where the ratio of female employment to male employment is already much higher than the other two blocs, the ratio further improve under the alternative scenario and it reaches $93.3 \%$ by 2030 .

\section{INSERT Table 11: Female employment as \% of male employment}

Under the expansionary gendered economic scenario significant gains are also made in terms of GDP growth. Table 12 summarizes the projected growth rates for each scenario. Growth rates for the austerity scenario are much lower than the gendered expansionary macroeconomic scenario. In the Eurozone periphery growth rates under the gendered expansionary (alternative) scenario reach an average of 3.4\% during the period 2019-2024 and $3 \%$ in the period 2025-2030. These rates are much higher than the austerity scenario where the growth rate is projected to remain below $1 \%$ for the whole period. Growth rates for the Core Eurozone and the United Kingdom, under the alternative scenario are more modest in comparison to those achieved by the Eurozone Periphery. However, both blocs perform better, in terms of economic growth, compared to the austerity scenario.

\section{INSERT Table 12: Average GDP growth (\%)}

Further, under our alternative scenario government spending in all blocs would increase faster than the number of economic dependents (young, elderly, or working age). Table 13 shows government spending per dependent measured in PPP\$ for the three blocs ${ }^{10}$.

\footnotetext{
${ }^{9}$ The Eurozone Periphery is a major recipient of migrants from within outside the EU. The figures quoted above therefore include the inflow of migrants in to the working age population.

${ }^{10}$ See appendix I for more information regarding the results for labour productivity.
} 


\section{INSERT Table 13: Government spending per dependent at PPP\$ rates}

In the Eurozone Periphery, for example government spending per dependent would rise from 10,439 PPP\$ to 18,471 PPP\$ under the alternative scenario. On the other hand, spending per dependent significantly declines under the austerity scenario. In the United Kingdom the corresponding increase would be from 15,149 PPP\$ in 2012 to 17,858 PPP\$ in 2020 and in the Core Eurozone government spending per dependent would increase by almost 5,000 PPP\$ by 2030. Thus, governments would improve their capacity to provide social protection and benefits to dependents under our alternative scenario. This is a crucial gender-aspect of our alternative scenario. Not only are jobs disproportionately created for women via this scenario, but, in addition, via the boost in targeted government spending, male and female dependents are further supported. The CAM does not provide a break-down of such spending by area but this may cover additional spending on care for children and elderly dependents as well as boosting allowances for non-working partners. The boost to such services inevitably also leads to the creation of further jobs for men and women within these sectors. This lends further support to our alternative scenario, compared to the businessas-usual case.

\section{Government balances}

The gendered expansionary macroeconomic scenario assumes that both private investment and government expenditure are marshalled to target significant increases in both female and male employment. Whilst changes in private investment are determined exogenously on the basis of historical data, government expenditure is estimated by the model. Table 14 shows the projected government spending as percentage of GDP to 2030 and the historical trends for the three blocs.

\section{INSERT Table 14: Government spending as \% of GDP}

Under the gendered expansionary macroeconomic (alternative) framework government spending as percentage of GDP for the Core Eurozone slightly declines from $24.6 \%$ to $23.1 \%$ in 2030. In the United Kingdom the reduction of government spending to GDP is more moderate compared to the austerity scenario where it reaches $19.5 \%$ by 2030 . In the Eurozone Periphery government expenditure increases to $25.8 \%$ by 2020 and subsequently declines by one percentage point by 2030. Overall, the gendered expansionary macroeconomic framework cannot be dismissed on the basis of fiscal profligacy. Instead a slower pace fiscal consolidation, especially in the Eurozone Periphery, could lead to higher levels of growth and more jobs for both women and men (see Appendix II for the longer-term implications for government debt).

Overall, the comparison of the austerity scenario with a gendered expansionary macroeconomic scenario reveals that the continuation of austerity policies, which translate in to significant cuts in government spending and investment, might lead to further stagnation in private investment, low growth rates across Europe, and more importantly it will impair job creation for both men and women. Further, continued austerity policies could lead to a stagnation of female employment and to a further deterioration of the ratio of female employment to male employment, thus further widening the employment gap. In contrast, a strategy of combining reflationary fiscal policies, increases in private investment, and carefully redirecting a significant part of government spending and investment towards the 
creation of jobs for women could have strong positive effects both in terms of employment generation and economic growth.

\section{Concluding remarks and ways forward}

It is increasingly evident that continued austerity policies are doing more harm than good for the economies and societies of Europe. However, the impact on gender equality is still to be fully understood. In particular, the multitude of channels and mechanisms through which women and men continue to be impacted by fiscal retrenchment makes drawing firm conclusions on the direction and severity of impacts difficult to determine.

This policy brief intended to make a modest contribution to this debate by tackling the impact of current austerity policies on employment in two Eurozone blocs, and by highlighting the economic implications of an alternative gender-focused employment-led policy approach.

Crucially, the analysis presented here shows that the aims of economic growth and increased employment targeted at women can be achieved via the adoption of gendersensitive expansionary macroeconomic policies. Such a macroeconomic strategy is economically feasible, leading to substantial gains in terms of job creation for both women and men, as well as accelerated growth and debt reduction. Thus, the recommendation that stems from this analysis is to roll back current austerity policies and embark on a new gendersensitive expansionary economic trajectory.

\section{REFERENCES}

Annesley, Claire. 2014. UK Austerity Policy: A Feminist Perspective, Friedrich Ebert Stiftung, January 2014.

Bagaria, Nitika, Dawn Holland and John Van Reenen. 2012. "Fiscal Consolidation in a Depression", National Institute Economic Review 221, July 2012.

Bettio, Francesca, et al. 2013. The impact of the economic crisis on the situation of women and men and on gender equality policies. Luxembourg: European Union.

Braunstein, Elissa, Irene Van Staveren and Daniela Tavani. 2011. "Embedding Care and Unpaid Work in Macroeconomic Modeling: A Structuralist Approach", Feminist Economics 17(4): 5-31.

Cripps, Francis and Naret Khurasee. 2010. "Introduction to the CAM databank and model". AUGUR, Challenges for Europe in the world in 2030. Deliverable 1.1, available from http://www.augurproject.eu/, access date 24/01/2014.

Cripps, Francis. 2014. "Macro-model scenarios and implications for European policy" in Eatwell, John, Terry McKinley, and Pascal Petit, eds. Challenges for Europe in the World of 2030. Farnham, Surrey: Ashgate Publishing.

Dauderstaedt, Michael and Ernst Hillebrandt, eds. 2013. Alternatives to Austerity:

Progressive Growth Strategies for Europe. Fridrich-Ebert Stiftung. December 2013. http://library.fes.de/pdf-files/id/ipa/10410.pdf

Eatwell, John, Terry McKinley and Pascal Petit, eds. 2014. Challenges for Europe in the World of 2030. Farnham, Surrey: Ashgate Publishing

European Commission. 2013. Smarter, greener, more inclusive? - Indicators to support the Europe 2020 strategy. Eurostat. Luxembourg: European Union.

European Federation of Public Service Unions. 2011. Widening the gender gap: the impact of public sector pay and job cuts on the employment and working conditions of women in four countries. Brussels: EPSU. 
European Women's Lobby. 2012. The price of austerity: The impact on women's rights and gender equality in Europe. Brussels: European Women's Lobby.

Eurostat. 2014. Eurostat Labour Market Surveys. Luxembourg: Eurostat. Available from http://epp.eurostat.ec.europa.eu/portal/page/portal/labour_market/introduction

Fontana, Marzia. 2014. 'Gender in economy-wide modelling', In Rai, Shirin M. and Waylen, Georgina, eds. New Frontiers in Feminist Political Economy, pp. 154-174. Oxford: Routledge

Gago, Elvira G. and Marcelo, S. Kirzner. 2013. "Women, gender equality and the economic crisis in Spain" in Karamessini, Maria and Jill Rubery, eds. Women and Austerity: The Economic Crisis and the Future for Gender Equality, pp. 228-247. Oxford: Routledge.

Griffith-Jones, Stephanie and Matthias Kollatz-Ahnen. 2013. Europe's economic crisis: some ideas for recovery and growth. The Guardian, Friday 16 August 2013, available from http://www.the guardian.com/, access date 25/01/2014.

Griffith-Jones, Stephanie, Matthias Kollatz-Ahnen, Lars Andersen and Signe Hansen. 2012. Shifting Europe from austerity to growth: a proposed investment programme for 20122015. FEPS-IPD-ECLM Policy Brief.

Gurmai, Zita. 2013. More gender equality is needed as a response to the current economic and financial crisis. Party of European Socialists. Available at http://www.pes.eu/ (access date 03 February 2014).

Himmelweit, Susan. and Hilary Land. 2008. "Reducing gender inequalities to create a sustainable care system” Joseph Rowntree Foundation Viewpoint Ref: 2293.

Karamessini, Maria. 2013. "Structural Crisis and Adjustment in Greece" in Karamessini, Maria and Jill Rubery, eds. Women and Austerity: The Economic Crisis and the Future for Gender Equality, pp.164-185. Oxford: Routledge.

Karamessini, Maria and Jill Rubery. 2013. "Economic crisis and austerity: challenges to gender equality" in Karamessini, Maria and Jill Rubery, eds. Women and Austerity: The Economic Crisis and the Future for Gender Equality, pp.314-351. Oxford: Routledge.

McKinley, Terry, Giovanni Cozzi, Jo Michell, and Hannah Bargawi. 2013a. Could Employment-Focused Policies Spearhead Economic Recovery in Europe? FEPS-CDPR Policy Brief No.4, August 2013.

McKinley, Terry, Giovanni Cozzi, and Jo Michell. 2013b. "Development, Demography and Migration" in Eatwell, John, Terry McKinley, and Pascal Petit, eds. Challenges for Europe in the World of 2030. Farnham, Surrey: Ashgate Publishing.

Onaran, Ozlem. 2013. "How to create more and better jobs via a wage-led recovery in Europe". Paper prepared for the Euromemo Conference, London 20-21 September 2013.

Ortiz, Isabel and Matthew Cummins. 2013a. "The Age of Austerity: A Review of Public

Expenditures and Adjustment Measures in 181 Countries." Initiative for Policy

Dialogue and the South Centre Working Paper.

Ortiz, Isabel and Matthew Cummins. 2013b. "Austerity Measures in Developing Countries: Public Expenditure Trends and the Risks to Children and Women" Feminist Economics 19(3): 55-81.

Perrons, Diane and Ania Plomien. 2013. "Gender, inequality and the crisis" in Karamessini, Maria and Jill Rubery, eds Women and Austerity. The economic crisis and the future for gender equality. pp.295-313. Oxford: Routledge.

Rai, Shirin M. and Georgina Waylen, eds. 2014. New Frontiers in Feminist Political Economy, Oxford: Routledge

Seguino, Stephanie. 2010. "TheGlobal Economic Crisis, Its Gender Implications, and Policy Responses." Gender and Development 18(2): 179-199.

UNISON. 2014. Counting the cost: how cuts are shrinking women's lives. London, UNISON. 
Van Staveren, Irene. 2014. "Gender as a macroeconomic variable" in Rai, Shirin M. and Georgina Waylen, eds. New Frontiers in Feminist Political Economy, pp.135-153. Oxford: Routledge

Verashchagina, Alina and Marina Capparucci. 2013. "Living through the crisis in Italy" in Karamessini, Maria and Jill Rubery, eds. Women and Austerity. The economic crisis and the future for gender equality. Pp.248-270. Oxford: Routledge.

Villa, Paola and Mark Smith. 2013. "Policy in the Time of Crisis: Employment Policy and Gender Equality in Europe" in Karamessini, Maria and Jill Rubery, eds. Women and Austerity. The economic crisis and the future for gender equality. Pp.273-294. Oxford: Routledge.

Women's Budget Group. 2012. Women's Budget Group Pre-Budget Briefing March 2012. http://wbg.org.uk/pdfs/0-WBG-pre-budget-FINAL.pdf 


\section{Appendix I: Results and analysis of labor productivity}

In addition to analysing employment and economic growth outcomes, we also compare increases in employment to increases in labor productivity. It is indeed desirable that economic policies produce a significant expansion in employment but not at the costs of losses in labor productivity. The ideal situation would be an improvement in both (McKinley et al. 2013a). Table A1 shows labor productivity, measured as GDP per person employed at PPP rates.

\section{INSERT Table A1: Labor productivity, GDP per person employed at PPP rates}

Under the gendered expansionary macroeconomic scenario labor productivity significantly rises. The most dramatic increases would occur in the Core Eurozone and in the Eurozone Periphery where GDP per person employed would reach 100,317 PPP\$ and 95,867 PPP\$ respectively by 2030. Also the United Kingdom records significant increases its labor productivity. By 2030 GDP per person employed in the United Kingdom wold reach 94,237 PPP\$. Thus, the gendered expansionary macroeconomic scenario achieves important gains not only in terms of job creation but also in terms of labor productivity. 


\section{Appendix II: Results and analysis of government debt}

In order to contain future government deficits our gendered expansionary macroeconomic scenario also assumes a boost in government income, in conjunction with the projected trend of government expenditure. For the three blocs we assume that net government income as a ratio to GDP rises to $22 \%$ by 2030 . Table A2 shows the fiscal balance as percentage of GDP for the three blocs under the two scenarios considered.

\section{INSERT Table A2: Fiscal balance as \% of GDP}

The combination of higher levels of growth and increases in government revenue in the gendered expansionary macroeconomic scenario leads to an improvement in the government deficit, to around $-3 \%$ of GDP in the Eurozone Periphery, and -1\% in the Core Eurozone and in the United Kingdom by 2030. The improvement in the Eurozone Periphery is much more modest than the austerity scenario, where fiscal deficit is eliminated by 2030 . However, the latter is achieved at the expense of lower GDP growth and less employment.

As a result of the trends in government expenditure and revenue, as well as the increases in GDP growth, government debt as a percentage of GDP declines more sharply in the gendered alternative scenario than in the austerity scenario for all the blocs (Table A3).

\section{INSERT Table A3: Government debt as \% of GDP}

In the South Eurozone government debt sharply declines to $82 \%$ of GDP by 2030 under the alternative scenario compared to $106.8 \%$ of GDP under the austerity scenario. Thus, we argue that a scenario of continued austerity in the South Eurozone would not only lead to stagnation of employment and inadequate growth rates, but would also fail to significantly reduce government debt. This is the case also for the United Kingdom where the debt to GDP ratio, under the gendered expansionary macroeconomic scenario, declines from $100 \%$ in 2012 to $62.5 \%$ in 2030. In the Core Eurozone, under the austerity scenario, debt to GDP ratio increase to $71 \%$ by 2030 whilst under the alternative scenario it remains below $60 \%$. 


\section{Tables and Figures - Engendering Economic Recovery:}

\section{Modelling Alternatives to Austerity in Europe}

Table 1: Review of austerity measures across Europe

Half-page table

Source: adapted from Ortiz and Cummins (2003a)

\begin{tabular}{|c|c|c|c|c|c|c|c|}
\hline Country & $\begin{array}{l}\text { Reducing } \\
\text { subsidies }\end{array}$ & $\begin{array}{l}\text { Wage bill } \\
\text { cuts/caps }\end{array}$ & $\begin{array}{l}\text { Increasing } \\
\text { consumption } \\
\text { taxes }\end{array}$ & $\begin{array}{l}\text { Pension } \\
\text { reform }\end{array}$ & $\begin{array}{c}\text { Rationalising } \\
\text { and } \\
\text { targeting } \\
\text { safety nets }\end{array}$ & $\begin{array}{l}\text { Health } \\
\text { reform }\end{array}$ & $\begin{array}{l}\text { Labour } \\
\text { Reform }\end{array}$ \\
\hline \multicolumn{8}{|l|}{$\begin{array}{l}\text { Eurozone } \\
\text { Periphery }\end{array}$} \\
\hline Greece & $\mathbf{x}$ & $\mathbf{x}$ & $x$ & $\mathbf{x}$ & $\mathbf{x}$ & $\mathbf{x}$ & $x$ \\
\hline Italy & $\mathbf{x}$ & $\mathbf{x}$ & $x$ & $\mathbf{x}$ & $\mathbf{x}$ & $\mathbf{x}$ & $x$ \\
\hline Ireland & $\mathbf{x}$ & $\mathbf{x}$ & $\mathbf{x}$ & $\mathbf{x}$ & $\mathbf{x}$ & $\mathbf{x}$ & $x$ \\
\hline Portugal & $\mathbf{x}$ & $\mathbf{x}$ & $x$ & $\mathbf{x}$ & $x$ & $x$ & $x$ \\
\hline Spain & $\mathbf{x}$ & $\mathbf{x}$ & $\mathbf{x}$ & $\mathbf{x}$ & $\mathbf{x}$ & $\mathbf{x}$ & $x$ \\
\hline \multicolumn{8}{|l|}{$\begin{array}{l}\text { Central } \\
\text { Eurozone }\end{array}$} \\
\hline Austria & $\mathbf{x}$ & & & $\mathbf{x}$ & & $x$ & \\
\hline Belgium & $\mathbf{x}$ & $\mathbf{x}$ & $x$ & $\mathbf{x}$ & $\mathbf{x}$ & $\mathbf{x}$ & $x$ \\
\hline France & & $\mathbf{x}$ & $x$ & $\mathbf{x}$ & $x$ & $\mathbf{x}$ & $x$ \\
\hline Germany & & & $\mathbf{x}$ & $\mathbf{x}$ & $x$ & $\mathbf{x}$ & \\
\hline Luxembourg & & & $x$ & $\mathbf{x}$ & $\mathbf{x}$ & $\mathbf{x}$ & $x$ \\
\hline Netherlands & $\mathbf{x}$ & $\mathbf{x}$ & $\mathbf{x}$ & $\mathbf{x}$ & $\mathbf{x}$ & $\mathbf{x}$ & $\mathbf{x}$ \\
\hline UK & $\mathbf{x}$ & $\mathbf{x}$ & $\mathbf{x}$ & $\mathbf{x}$ & & & \\
\hline
\end{tabular}


Figure 1: Public sector employment in the Eurozone (2010-2013)

See excel file - fig 1

Full page figure

Source: EUROSTAT 2014 'Full-time and part-time employment by sex and economic activity'.

Male Full-time Public Sector Employment (as prop. of 2010 figures)

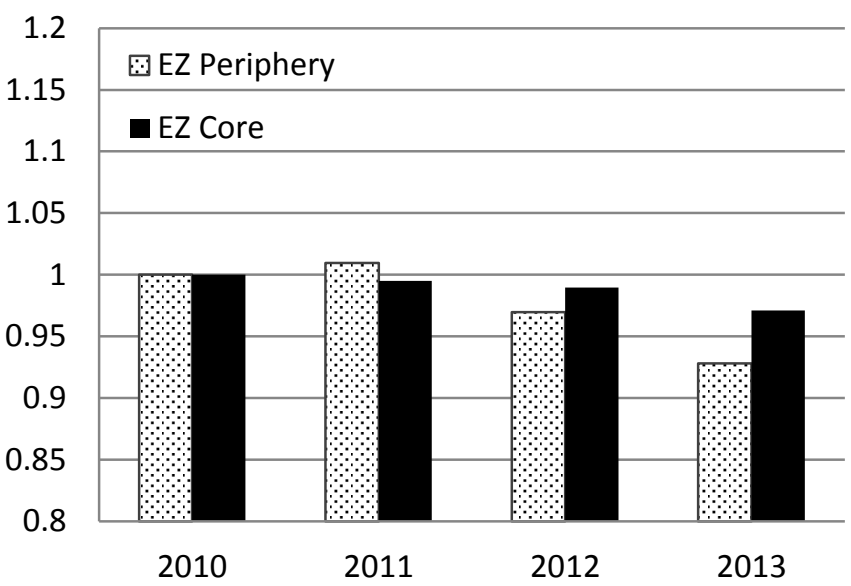

Male PT Public Sector Employment (as proportion of 2010 figures)

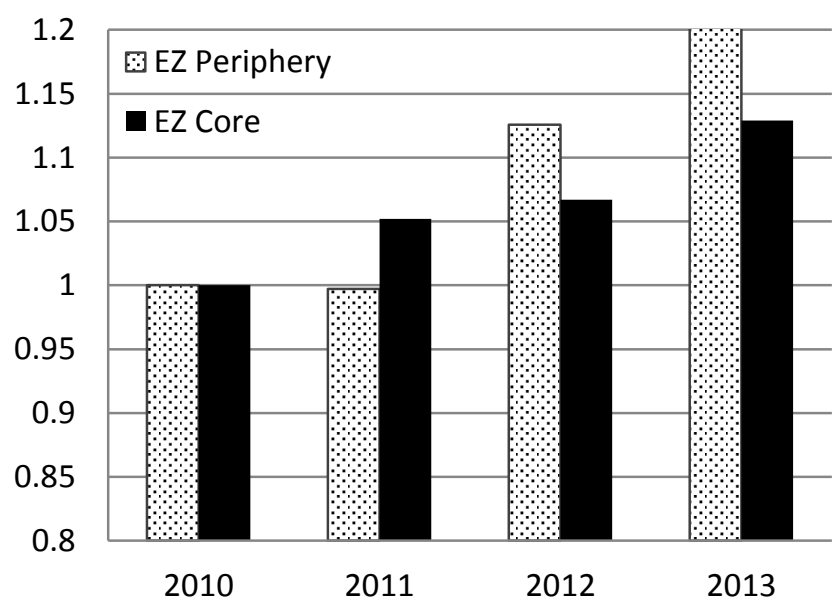

Female Full-time Public Sector Employment (as prop. of 2010 figures)

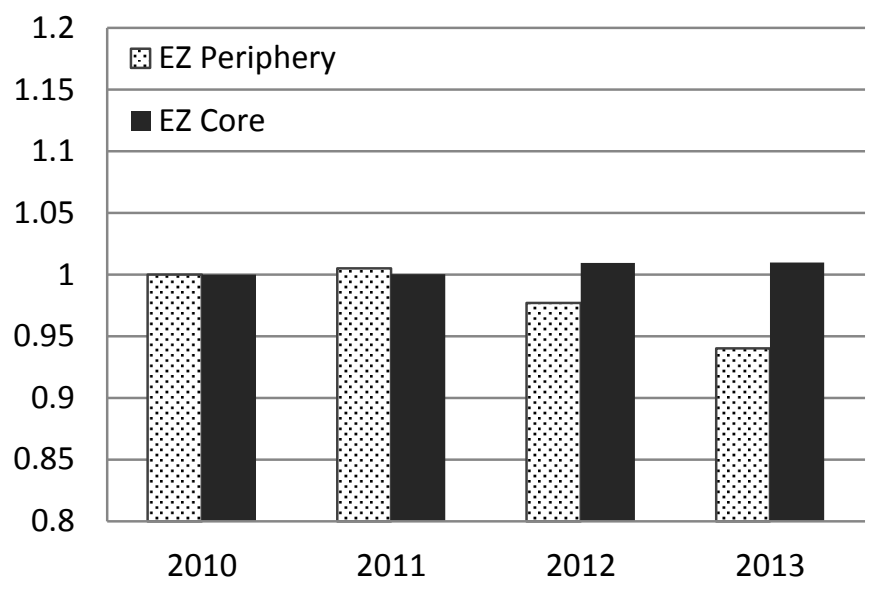

Female PT Public Sector Employment (as proportion of 2010 figures)

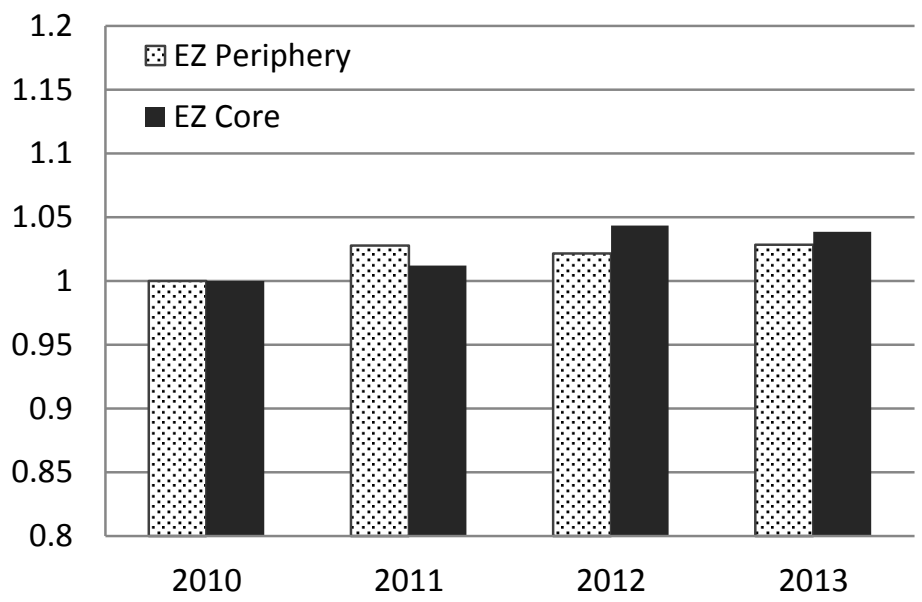


Table 2: The gender pay gap in the public sector in Europe (2008-2012) Half-page table

Source: EUROSTAT 2014 'Structure of Earnings Survey'

\begin{tabular}{|c|c|c|c|c|c|}
\hline GEO/TIME & 2008 & 2009 & 2010 & 2011 & 2012 \\
\hline Ireland & 24.9 & 23.7 & 21.1 & 19.6 & 23.3 \\
\hline Greece & na & na & na & na & na \\
\hline Spain & 17.1 & 17.8 & 17.4 & 18.2 & 18.2 \\
\hline Italy & na & na & na & na & na \\
\hline Portugal & 24.3 & 25.3 & 24.2 & 23.3 & 20.7 \\
\hline United Kingdom & 24.6 & 25.1 & 23.8 & 23.8 & 23.4 \\
\hline Belgium & 6.5 & 6.4 & 6.4 & 6.1 & 6 \\
\hline Germany & 18.6 & 17.8 & 17.1 & 17 & 16.4 \\
\hline France & 17.2 & 15.9 & 16.1 & 14.8 & 16.4 \\
\hline Luxembourg & 9.1 & 7.5 & 6 & 6 & 5.2 \\
\hline Netherlands & 19.7 & 19.4 & 18.9 & 17.9 & 17 \\
\hline Austria & na & na & na & na & na \\
\hline EZ Periphery simple average & 22.1 & 22.2 & 20.9 & 20.3 & 20.7 \\
\hline $\begin{array}{l}\text { EZ Core (and UK) simple } \\
\text { average }\end{array}$ & 15.9 & 15.3 & 14.7 & 14.2 & 14 \\
\hline
\end{tabular}

Table 3: Female discouraged workers ${ }^{11}$ as $\%$ of total active population (2008-2012)

Half-page table

Source: EUROSTAT 2014 'Full-time and part-time employment by sex and economic activity'.

GEO/TIME

$\begin{array}{llllll}2008 & 2009 & 2010 & 2011 & 2012\end{array}$

Ireland

$0.6 \quad 1.1$

1.3

1.6

1.8

1.6

Greece

1.7

2

2.3

2.9

3.3

Spain

5.6

6.2

6.3

6.1

$\begin{array}{ll}6.7 & 7.2\end{array}$

Italy

16.8

15.9

16.6

16.8

17.2

17.5

Portugal

1.7

1.6

1.8

4

5.2

6.2

United

2.7

2.9

3

2.8

2.9

2.7

Kingdom

Belgium

1

0.9

0.9

2.5

2.2

2.3

${ }^{11}$ Discouraged workers are identified as persons available to work but not seeking work. 


$\begin{array}{lcccccc}\text { Germany } & 2 & 2.2 & 1.6 & 1.8 & 1.7 & 1.6 \\ \text { France } & 1.4 & 1.4 & 1.3 & 1.3 & 1.2 & \text { na } \\ \text { Luxembourg } & 0.7 & 7.1 & 6.6 & 7.3 & 7.3 & 8.3 \\ \text { Netherlands } & 3.4 & 3.5 & 3.9 & 3.5 & 3.8 & 4.3 \\ \text { Austria } & 4.1 & 4.2 & 4 & 3.7 & 3.7 & 3.7 \\ \begin{array}{l}\text { EZ Periphery } \\ \text { EZ Core and }\end{array} & \mathbf{5 . 3} & \mathbf{5 . 4} & \mathbf{5 . 6} & \mathbf{6 . 2} & \mathbf{6 . 8} & \mathbf{7 . 2} \\ \text { UK } & \mathbf{2 . 2} & \mathbf{3 . 2} & \mathbf{3} & \mathbf{3 . 3} & \mathbf{3 . 3} & \mathbf{3 . 8}\end{array}$


Table 4: Target government expenditure ${ }^{12}$ as percentage of GDP under austerity and historical values

Half-page table

\begin{tabular}{|c|c|c|c|c|}
\hline & \multicolumn{3}{|c|}{$\begin{array}{l}\text { Historical } \\
\text { Values }\end{array}$} & \multirow[t]{2}{*}{$\begin{array}{l}2030 \text { Target: government } \\
\text { expenditure (GV) } \\
\text { (Austerity scenario) }\end{array}$} \\
\hline & 2000 & 2008 & 2012 & \\
\hline $\begin{array}{l}\text { Core } \\
\text { Eurozone }\end{array}$ & $22 \%$ & $23 \%$ & $25 \%$ & $21 \%$ \\
\hline $\begin{array}{l}\text { Eurozone } \\
\text { Periphery }\end{array}$ & $20 \%$ & $23 \%$ & $25 \%$ & $19 \%$ \\
\hline $\begin{array}{l}\text { United } \\
\text { Kingdom }\end{array}$ & $19 \%$ & $25 \%$ & $26 \%$ & $20 \%$ \\
\hline
\end{tabular}

Table 5: Target government income as percentage of GDP under austerity and historical values

Half-page table

\begin{tabular}{|c|c|c|c|c|}
\hline & \multicolumn{3}{|c|}{ Historical } & \multirow{2}{*}{$\begin{array}{c}2030 \text { Target: } \\
\text { government } \\
\text { income (Yg) } \\
\text { (Austerity } \\
\text { scenario) }\end{array}$} \\
\hline & 2000 & 2008 & 2012 & \\
\hline Core Eurozone & 22.5 & 22 & 20 & $20 \%$ \\
\hline $\begin{array}{l}\text { Eurozone } \\
\text { Periphery }\end{array}$ & 19.4 & 18.8 & 16.1 & $20 \%$ \\
\hline $\begin{array}{l}\text { United } \\
\text { Kingdom }\end{array}$ & 22.9 & 19.2 & 15.6 & $19 \%$ \\
\hline
\end{tabular}

12 Government expenditure excludes transfer payments such as social security and pensions. Thus the ratios shown are considerably smaller than the gross figure usually quoted. 
Table 6: Employment as percentage of working-age-population: targets and historical levels See excel file - tab 6

Half-page table

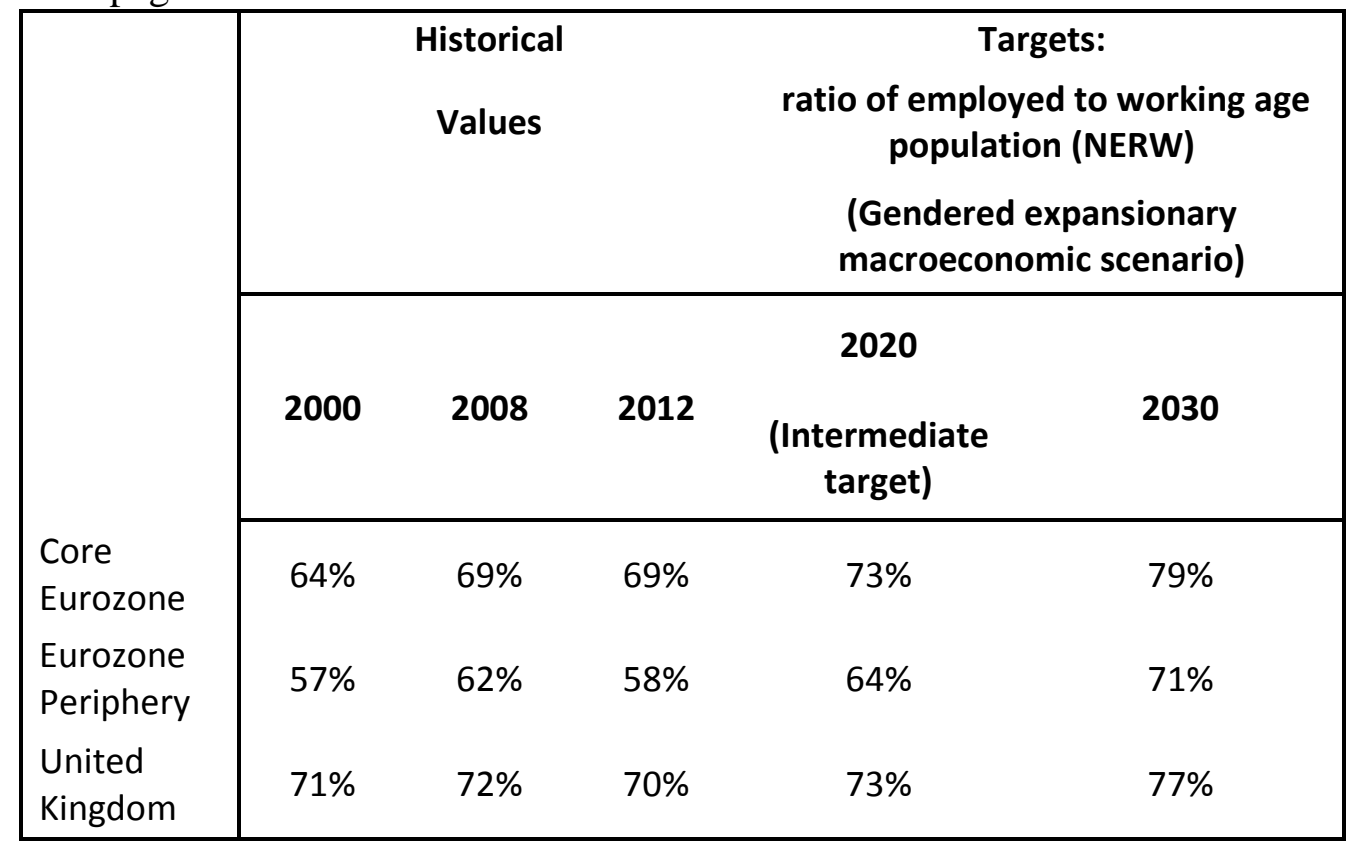

Table 7: Female and male employment targets

Half-page table

\begin{tabular}{|c|c|c|c|c|}
\hline \multicolumn{5}{|c|}{$\begin{array}{l}\text { Female employment as percentage of female } \\
\text { working age population (NERFW) }\end{array}$} \\
\hline & \multicolumn{3}{|c|}{$\begin{array}{l}\text { Historical } \\
\text { Values }\end{array}$} & \multirow{2}{*}{$\begin{array}{l}\text { Targets: } \\
2030\end{array}$} \\
\hline & 2000 & 2008 & 2012 & \\
\hline Core EZ & $57 \%$ & $64 \%$ & $65 \%$ & $77 \%$ \\
\hline $\begin{array}{l}\text { EZ } \\
\text { Periphery }\end{array}$ & $43 \%$ & $52 \%$ & $50 \%$ & $67 \%$ \\
\hline UK & $65 \%$ & $66 \%$ & $65 \%$ & $73 \%$ \\
\hline \multicolumn{5}{|c|}{$\begin{array}{c}\text { Male employment as percentage of male working } \\
\text { age population (NERMW) }\end{array}$} \\
\hline & \multicolumn{3}{|c|}{$\begin{array}{l}\text { Historical } \\
\text { Values }\end{array}$} & Targets: \\
\hline & 2000 & 2008 & 2012 & 2030 \\
\hline Core EZ & $72 \%$ & $74 \%$ & $74 \%$ & $81 \%$ \\
\hline $\begin{array}{l}\text { EZ } \\
\text { Periphery }\end{array}$ & $71 \%$ & $73 \%$ & $67 \%$ & $76 \%$ \\
\hline UK & $78 \%$ & $78 \%$ & $75 \%$ & $81 \%$ \\
\hline
\end{tabular}


Table 8: Private investment targets and historical values Half-page table

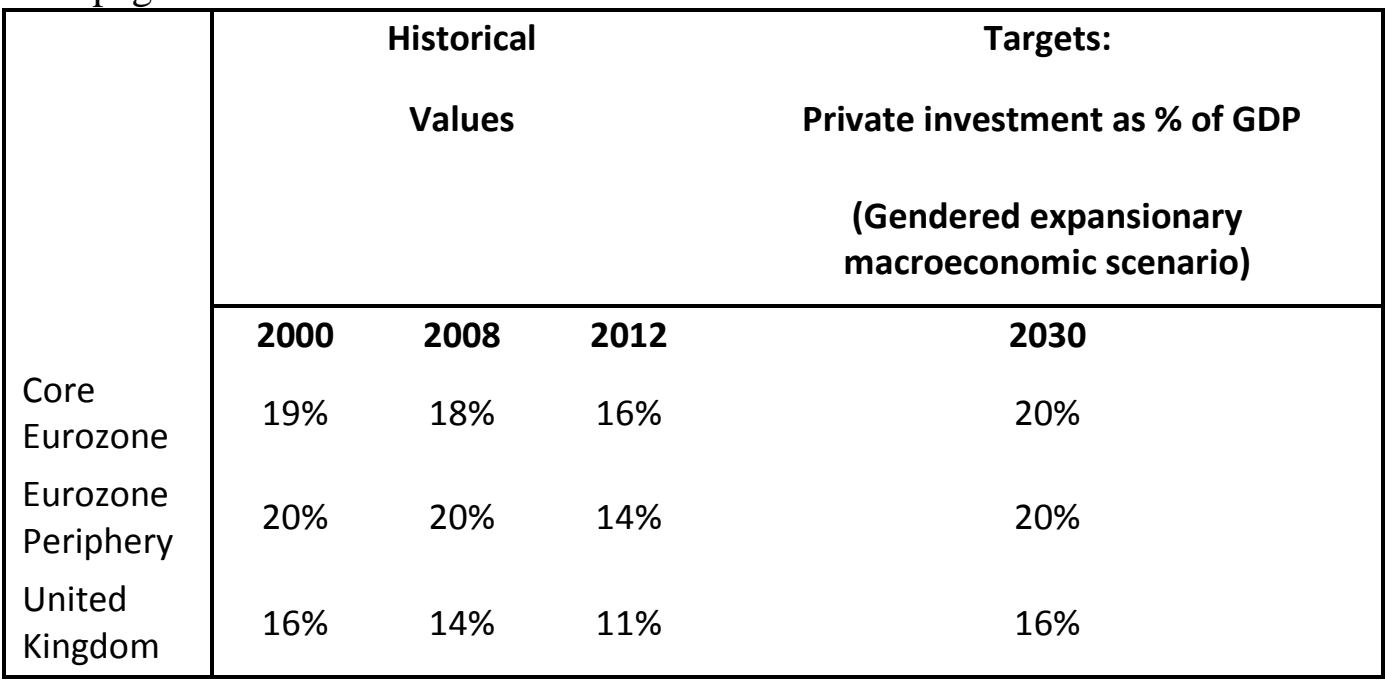

Table 9: Total employment (millions of persons)

Half-page table

\begin{tabular}{|l|lcccccc|}
\hline & & 2000 & 2008 & 2012 & 2020 & 2025 & 2030 \\
\hline \multirow{5}{*}{ Core Eurozone } & Historical & 79.08 & 86.29 & 86.29 & & & \\
& Austerity & & & & 87.63 & 86.65 & 84.79 \\
& Alternative & & & & 89.36 & 89.59 & 89.26 \\
& Difference & & & & 1.72 & $\mathbf{2 . 9 5}$ & $\mathbf{4 . 4 8}$ \\
\hline \multirow{5}{*}{$\begin{array}{l}\text { Eurozone } \\
\text { Periphery }\end{array}$} & Historical & 47.72 & 55.81 & 52.8 & & & \\
& Austerity & & & & 52.43 & 52.49 & 52.51 \\
& Alternative & & & & 56.86 & 59.2 & 60.86 \\
& Difference & & & & 4.42 & $\mathbf{6 . 7 2}$ & $\mathbf{8 . 3 5}$ \\
\hline \multirow{5}{*}{ United Kingdom } & Historical & 27.29 & 29.22 & 28.91 & & & \\
& austerity & & & & 29.13 & 29.09 & 29.14 \\
& alternative & & & & 29.86 & 30.15 & 30.47 \\
& difference & & & & $\mathbf{0 . 7 3}$ & $\mathbf{1 . 0 6}$ & $\mathbf{1 . 3 3}$ \\
\hline
\end{tabular}


Table 10: Total female employment (in millions)

Half-page table

\begin{tabular}{|c|c|c|c|c|c|c|c|}
\hline & & 2000 & 2008 & 2012 & 2020 & 2025 & 2030 \\
\hline \multirow{4}{*}{ Core Eurozone } & Historical & 34.8 & 39.49 & 40.16 & & & \\
\hline & Austerity & & & & 41.43 & 41.19 & 40.33 \\
\hline & Alternative & & & & 42.33 & 42.87 & 43.08 \\
\hline & Difference & & & & 0.9 & 1.68 & 2.75 \\
\hline \multirow{4}{*}{ Eurozone Periphery } & Historical & 18.02 & 23.11 & 22.43 & & & \\
\hline & Austerity & & & & 21.95 & 21.89 & 21.91 \\
\hline & Alternativ & & & & 25.16 & 26.6 & 27.74 \\
\hline & Difference & & & & 3.21 & 4.71 & 5.82 \\
\hline \multirow{4}{*}{ United Kingdom } & Historical & 12.48 & 13.45 & 13.47 & & & \\
\hline & Austerity & & & & 13.54 & 13.45 & 13.38 \\
\hline & Alternativ & & & & 13.91 & 14.04 & 14.17 \\
\hline & Difference & & & & 0.37 & 0.59 & 0.79 \\
\hline
\end{tabular}

Table 11: Female employment as $\%$ of male employment

Half-page table

\begin{tabular}{|l|lrrrrr|}
\hline & & 2000 & 2008 & 2012 & 2020 & 2030 \\
\hline Core Eurozone & Historical & 78.6 & 85.6 & 87.1 & & \\
& Austerity & & & & 89.7 & 90.7 \\
& Alternative & & & & 90 & 93.3 \\
\hline Eurozone Periphery & Historical & 60.7 & 70.7 & 73.8 & & \\
& Austerity & & & & 72 & 71.6 \\
& Alternative & & & & 79.4 & 83.7 \\
\hline United Kingdom & Historical & 84.3 & 85.3 & 86.9 & & \\
& Austerity & & & & 86.8 & 84.9 \\
& Alternative & & & & 87.2 & 86.9 \\
\hline
\end{tabular}

Table 12: Average GDP growth (\%)

Half-page table

\begin{tabular}{|l|lllccc|}
\hline & & $\mathbf{2 0 0 1 -}$ & $\mathbf{2 0 0 7 -}$ & $\mathbf{2 0 1 3 -}$ & $\mathbf{2 0 1 9 -}$ & $\mathbf{2 0 2 5 -}$ \\
& & $\mathbf{2 0 0 6}$ & $\mathbf{2 0 1 2}$ & $\mathbf{2 0 1 8}$ & $\mathbf{2 0 2 4}$ & $\mathbf{2 0 3 0}$ \\
\hline \multirow{4}{*}{ Core Eurozone } & Historical & 1.6 & -0.7 & & & \\
& Austerity & & & 1.6 & 1.1 & 0.5 \\
& Alternative & & & 2.1 & 1.9 & 1.7 \\
\hline \multirow{3}{*}{ Eurozone Periphery } & Historical & 2.3 & -0.7 & & & \\
& Austerity & & & 0 & 0.7 & 0.7 \\
& Alternative & & & 2.4 & 3.4 & 3 \\
\hline \multirow{3}{*}{ United Kingdom } & Historical & 2.9 & 0.2 & & & \\
& Austerity & & & 1 & 1.2 & 1.4 \\
& Alternative & & & 1.8 & 2 & 2.2 \\
\hline
\end{tabular}


Table 13: Government spending per dependent at PPP\$ rates

Half-page table

\begin{tabular}{|l|lrrrrr|}
\hline & & $\mathbf{2 0 0 0}$ & $\mathbf{2 0 0 8}$ & $\mathbf{2 0 1 2}$ & $\mathbf{2 0 2 0}$ & $\mathbf{2 0 3 0}$ \\
\hline Core Eurozone & Historical & 11,888 & 13,981 & 14,802 & & \\
& Austerity & & & & 14,868 & 14,780 \\
& Alternative & & & & 16,488 & 19,737 \\
\hline Eurozone Periphery & Historical & 8,400 & 11,042 & 10,439 & & \\
& Austerity & & & & 9,036 & 8,395 \\
& Alternative & & & & 13,712 & 18,471 \\
\hline United Kingdom & Historical & 10,464 & 15,550 & 15,149 & & \\
& Austerity & & & & 13,580 & 12,832 \\
& Alternative & & & & 15,570 & 17,854 \\
\hline
\end{tabular}

Table 14: Government spending as \% of GDP

Half-page table

\begin{tabular}{|l|lrrrrrr|}
\hline & & 2000 & 2008 & 2012 & 2015 & 2020 & 2030 \\
\hline \multirow{3}{*}{ Core Eurozone } & Historical & 22.4 & 23.1 & 24.6 & & & \\
& Austerity & & & & 21.7 & 21.6 & 21 \\
& Alternative & & & & 24.1 & 23.3 & 23.1 \\
\hline \multirow{3}{*}{ Eurozone Periphery } & Historical & 20.3 & 23.3 & 25.4 & & & \\
& Austerity & & & & 22.4 & 19.9 & 18.5 \\
& Alternative & & & & 25.1 & 25.8 & 24.8 \\
\hline \multirow{3}{*}{ United Kingdom } & Historical & 19.7 & 24.7 & 26 & & & \\
& Austerity & & & & 22.5 & 20.9 & 19.5 \\
& Alternative & & & & 24.8 & 23.8 & 22.8 \\
\hline
\end{tabular}

Table A1: Labor productivity, GDP per person employed at PPP rates

Half-page table

\begin{tabular}{|l|lrrrrr|}
\hline & & $\mathbf{2 0 0 0}$ & $\mathbf{2 0 0 8}$ & $\mathbf{2 0 1 2}$ & $\mathbf{2 0 2 0}$ & $\mathbf{2 0 3 0}$ \\
\hline Core Eurozone & Historical & 69,477 & 73,313 & 73,562 & & \\
& Austerity & & & & 81,735 & 90,527 \\
& Alternative & & & & 84,211 & 100,317 \\
\hline Eurozone Periphery & Historical & 66,349 & 66,377 & 65,739 & & \\
& Austerity & & & & 66,831 & 71,483 \\
& Alternative & & & & 75,626 & 95,867 \\
\hline United Kingdom & Historical & 61,126 & 69,387 & 69,122 & & \\
& Austerity & & & & 74,470 & 84,844 \\
& Alternative & & & & 77,665 & 94,237 \\
\hline
\end{tabular}


Table A2: Fiscal balance as \% of GDP

Half-page table

\begin{tabular}{|l|lllccc|}
\hline & & $\mathbf{2 0 0 0}$ & $\mathbf{2 0 0 8}$ & $\mathbf{2 0 1 2}$ & $\mathbf{2 0 2 0}$ & $\mathbf{2 0 3 0}$ \\
\hline Core Eurozone & Historical & 0.1 & -1.1 & -5.1 & & \\
& Austerity & & & & -2.3 & -1 \\
& Alternative & & & & -1.7 & -1.1 \\
\hline Eurozone Periphery & Historical & -0.8 & -4.5 & -9.3 & & \\
& Austerity & & & & -1.9 & 1.5 \\
& Alternative & & & & -4.8 & -2.9 \\
\hline United Kingdom & Historical & 3.2 & -5.4 & -10.3 & & \\
& Austerity & & & & -3.7 & -0.5 \\
& Alternative & & & & -3.5 & -1.1 \\
\hline
\end{tabular}

Table A3: Government debt as \% of GDP

Half-page table

\begin{tabular}{|c|c|c|c|c|c|c|c|c|}
\hline & & 2000 & 2008 & 2010 & 2011 & 2012 & 2020 & 2030 \\
\hline \multirow[t]{3}{*}{ Core Eurozone } & Historical & 52.1 & 51.4 & 61.3 & 61.8 & 63.3 & & \\
\hline & Austerity & & & & & & 70.1 & 71.6 \\
\hline & Alternative & & & & & & 56.6 & 54.4 \\
\hline \multirow[t]{3}{*}{ Eurozone Periphery } & Historical & 84.1 & 69.7 & 91.2 & 93.4 & 100.3 & & \\
\hline & Austerity & & & & & & 129.7 & 106.8 \\
\hline & Alternative & & & & & & 92.5 & 82 \\
\hline \multirow[t]{3}{*}{ United Kingdom } & Historical & 46.6 & 51.6 & 96.4 & 100.2 & 100.5 & & \\
\hline & Austerity & & & & & & 122 & 107.7 \\
\hline & Alternative & & & & & & 79 & 62.5 \\
\hline
\end{tabular}

